\title{
Varietal Screening of Sapota against Insect Pest Complex
}

\author{
A.S. Vaja ${ }^{*}$, V.R. Virani, K.A. Chudasama and S.R. Dhandge \\ Department of Entomology, College of Agriculture, Junagadh Agricultural University, \\ Junagadh-362001(Gujarat), India \\ *Corresponding author
}

\section{A B S T R A C T}

\section{Keywords \\ Sapota, Chiku moth \\ (Nephopteryx eugraphellea \\ Ragonot), bud borer (Anarsic \\ achrasella Bradley), Leaf \\ miner (Achrocercops \\ gemoniella Stainton), Midrib \\ folder (Banisia myrsusales \\ earalis Walker) \\ Article Info \\ Accepted: \\ 07 October 2018 \\ Available Online: \\ 10 November 2018}

The eight varieties of sapota were screened for their susceptibility against infestation of sapota insect pest complex, an experiment was conducted under field condition at the RTTC Farm (Research Training and Testing Center) of Junagadh Agricultural University, Junagadh during the year 2017. Among the eight varieties PKM-1 found least susceptible against infestation of chiku moth, bud borer and midrib folder while Cricket ball found least susceptible against infestation of leaf miner. Variety of Cricket ball was recorded as highly susceptible against twig damage by chiku moth and bud damage by bud borer while Kalipatti recorded highly susceptible against bud damage by chiku moth as well as leaves damage by midrib folder, however variety Mohangoottee was recorded as highly susceptible against leaves damage by leaf miner.

\section{Introduction}

The sapota Manilkara achras (Miller) Fosberg. belongs to family Sapotaceae, is commonly known as chiku, ciku, nasberry, sapodilla, chico. It is native of Maxico and Central America and now widely cultivated throughout the tropics. The pulp of fruit is useful for preparation of sherbet and halwa (Singh et al., 1963). The ripen fruits are used for making jams, jellies, osmodehydrated slices and squash (Reddy, 1959). The fruit greatly vary in size and shape. There are varieties which produce characteristically round fruits such as Calcutta round, Cricket Ball and Barmasi whereas the varieties such as
Badam, Oval, Guthi and Vavivalasa produce oval shaped fruits. The varieties Kalipatti and Chattri produce both round and oval shaped fruits on the same tree (Gandhi, 1956). In India, sapota ranks fifth in both production and consumption next to mango, banana, citrus and grape (Tsomu et al., 2015). It is largely grown for commercial purpose in Gujarat, Maharashtra, Karnataka, Tamil Nadu, Kerala, Uttar Pradesh, Haryana, Punjab and West Bengal (Cheema et al., 1954). In India sapota is cultivated in 99 lakh ha area with a total production of 1236 lakh MT (Anon., 2018 a). In Gujarat, it is grown under 30,010 ha area with a production of 3.31 lakh MT (Anon., 2018 b). The sapota has flowering and 
fruiting throughout the year in warm and humid climatic condition that also favorable for insect pests and diseases. More than 25 insect pests attacked to sapota tree (Butani, 1979). Among the different insect pests attacking sapota, chiku moth (Nephopteryx eugraphella), bud borer (Anarsia achrasella) are major pests of sapota and active throughout the year on sapota tree. Therefore, present investigation was carried on screening of different sapota varieties against sapota insect pests in a South Saurashtra region of Gujarat under Junagadh condition.

\section{Materials and Methods}

To study the screening of different sapota varieties against sapota insect pests, the experiment was laid out in CRD (Completely Randomized Design). Sapota varieties were planted earlier at $8 \mathrm{~m} \times 8 \mathrm{~m}$ At the Jambuwadi Farm, Junagadh Agricultural University, Junagadh.

For these purpose three trees of each variety as three repetitions per treatment selected. Total eight twigs $(20 \mathrm{~cm}$ length) per tree were selected ( 2 twigs from each side of tree, total twenty four twigs was selected from each variety). Observations of infestation of sapota insect pest complex were recorded at fortnightly interval throughout year. From each variety for recording the per cent infestation of various plant parts of sapota due to different insect pests were calculated with the help of the following formula.

Number of damaged leaves/buds/flowers/twigs

Per cent infestation $=$ X 100

Total number of leaves/buds/flowers/twigs

\section{Observations recorded}

Per cent (\%) damaged twigs of sapota by chiku moth (N. eugraphella).
Per cent (\%) damaged leaves of sapota by midrib folder (B. myrsusales earalis) and leaf miner (A. gemoniella).

Per cent $(\%)$ damaged buds of sapota by bud borer (A. achrasella) and chiku moth ( $N$. eugraphella).

\section{Results and Discussions}

\section{Varietal screening of sapota against infestation of chiku moth}

\section{Twig damage}

The result shown in Table 1 and graphically depicted in Figure 1 revealed that all varieties showed more or less twig damage. Among eight varieties of sapota tested, the variety of Cricket ball showed most susceptible 4.03 per cent infestation and it was at par with Kalipatti 3.80 per cent infestation.

While variety Pilipatti showed moderately susceptible 1.91 per cent infestation followed by Mohangoottee, Bhuripatti, Zumakhiya and Calcutti special were recorded 2.25, 2.49, 3.01 and 3.60 per cent infestation, respectively. Variety PKM-1 showed least susceptible 1.64 per cent infestation.

\section{Bud damage}

The result shown in Table 1 and graphically depicted in Figure 1 indicated that all varieties showed more or less bud damage. Among eight variety of sapota tested the varieties of Kalipatti showed most susceptible 4.60 per cent infestation. While variety Mohangoottee showed moderately susceptible 1.62 per cent infestation followed by Bhuripatti, Pilipatti, Zumakhiya, Calcutti special and Cricket ball were recorded 1.97, 2.18, 2.86, 3.02 and 4.27 per cent infestation, respectively. The variety PKM-1 showed least susceptible 1.44 per cent infestation. 
Table.1 Screening of various varieties of sapota against infestation of sapota insect pest complex during year 2017

\begin{tabular}{|c|c|c|c|c|c|c|}
\hline \multirow[t]{2}{*}{ Sr. No. } & \multirow[t]{2}{*}{ Treatment } & \multicolumn{5}{|c|}{ Per cent infestation caused by different insect of sapota } \\
\hline & & $\begin{array}{c}\text { Infestation of } \\
\text { chiku moth on } \\
\text { twig }\end{array}$ & $\begin{array}{l}\text { Infestation of } \\
\text { chiku moth on } \\
\text { bud }\end{array}$ & $\begin{array}{l}\text { Infestation of } \\
\text { bud borer on } \\
\text { bud }\end{array}$ & $\begin{array}{l}\text { Infestation of } \\
\text { leaf miner on } \\
\text { leaves }\end{array}$ & $\begin{array}{l}\text { Infestation of } \\
\text { midrib folder on } \\
\text { leaves }\end{array}$ \\
\hline 1. & Kalipatti & $\begin{array}{l}11.25 \\
(3.80)\end{array}$ & $\begin{array}{l}12.38 \\
(4.60)\end{array}$ & $\begin{array}{c}13.08 \\
(5.12)\end{array}$ & $\begin{array}{l}14.65 \\
(6.40)\end{array}$ & $\begin{array}{l}17.08 \\
(8.63)\end{array}$ \\
\hline 2. & Zumakhiya & $\begin{array}{c}9.99 \\
(3.01)\end{array}$ & $\begin{array}{c}9.74 \\
(2.86)\end{array}$ & $\begin{array}{c}10.70 \\
(3.45)\end{array}$ & $\begin{array}{l}11.99 \\
(4.32)\end{array}$ & $\begin{array}{c}13.30 \\
(5.29)\end{array}$ \\
\hline 3. & Bhuripatti & $\begin{array}{c}9.08 \\
(2.49)\end{array}$ & $\begin{array}{c}8.07 \\
(1.97)\end{array}$ & $\begin{array}{c}9.90 \\
(2.96)\end{array}$ & $\begin{array}{l}12.59 \\
(4.75)\end{array}$ & $\begin{array}{c}14.84 \\
(6.56)\end{array}$ \\
\hline 4. & Calcutti special & $\begin{array}{c}10.93 \\
(3.60)\end{array}$ & $\begin{array}{l}10.00 \\
(3.02)\end{array}$ & $\begin{array}{l}12.68 \\
(4.82)\end{array}$ & $\begin{array}{c}13.46 \\
(5.42)\end{array}$ & $\begin{array}{l}15.36 \\
(7.02)\end{array}$ \\
\hline 5. & Mohangoottee & $\begin{array}{c}8.62 \\
(2.25)\end{array}$ & $\begin{array}{c}7.32 \\
(1.62)\end{array}$ & $\begin{array}{c}9.54 \\
(2.75)\end{array}$ & $\begin{array}{r}16.28 \\
(7.86)\end{array}$ & $\begin{array}{l}12.26 \\
(4.51)\end{array}$ \\
\hline 6. & Pilipatti & $\begin{array}{c}7.95 \\
(1.91)\end{array}$ & $\begin{array}{c}8.49 \\
(2.18)\end{array}$ & $\begin{array}{c}9.28 \\
(2.60)\end{array}$ & $\begin{array}{c}10.93 \\
(3.60)\end{array}$ & $\begin{array}{c}11.33 \\
(3.86)\end{array}$ \\
\hline 7. & Cricket ball & $\begin{array}{l}11.57 \\
(4.03)\end{array}$ & $\begin{array}{l}11.92 \\
(4.27)\end{array}$ & $\begin{array}{c}13.71 \\
(5.62)\end{array}$ & $\begin{array}{c}9.51 \\
(2.73)\end{array}$ & $\begin{array}{l}16.60 \\
(8.16)\end{array}$ \\
\hline 8. & PKM-1 & $\begin{array}{c}7.35 \\
(1.64)\end{array}$ & $\begin{array}{c}6.90 \\
(1.44)\end{array}$ & $\begin{array}{c}8.89 \\
(2.39)\end{array}$ & $\begin{array}{c}9.92 \\
(2.97)\end{array}$ & $\begin{array}{l}10.18 \\
(3.13)\end{array}$ \\
\hline & S.Em \pm & 0.20 & 0.07 & 0.22 & 0.16 & 0.14 \\
\hline & .D. at $5 \%$ & 0.59 & 0.19 & 0.64 & 0.46 & 0.42 \\
\hline & C.V.\% & 4.50 & 5.19 & 4.27 & 2.72 & 2.21 \\
\hline
\end{tabular}

The figures in parentheses are retransformed values, those outside are arcsine transformed values. 
Fig.1 Varietal screening of sapota against infestation of sapota insect pest complex

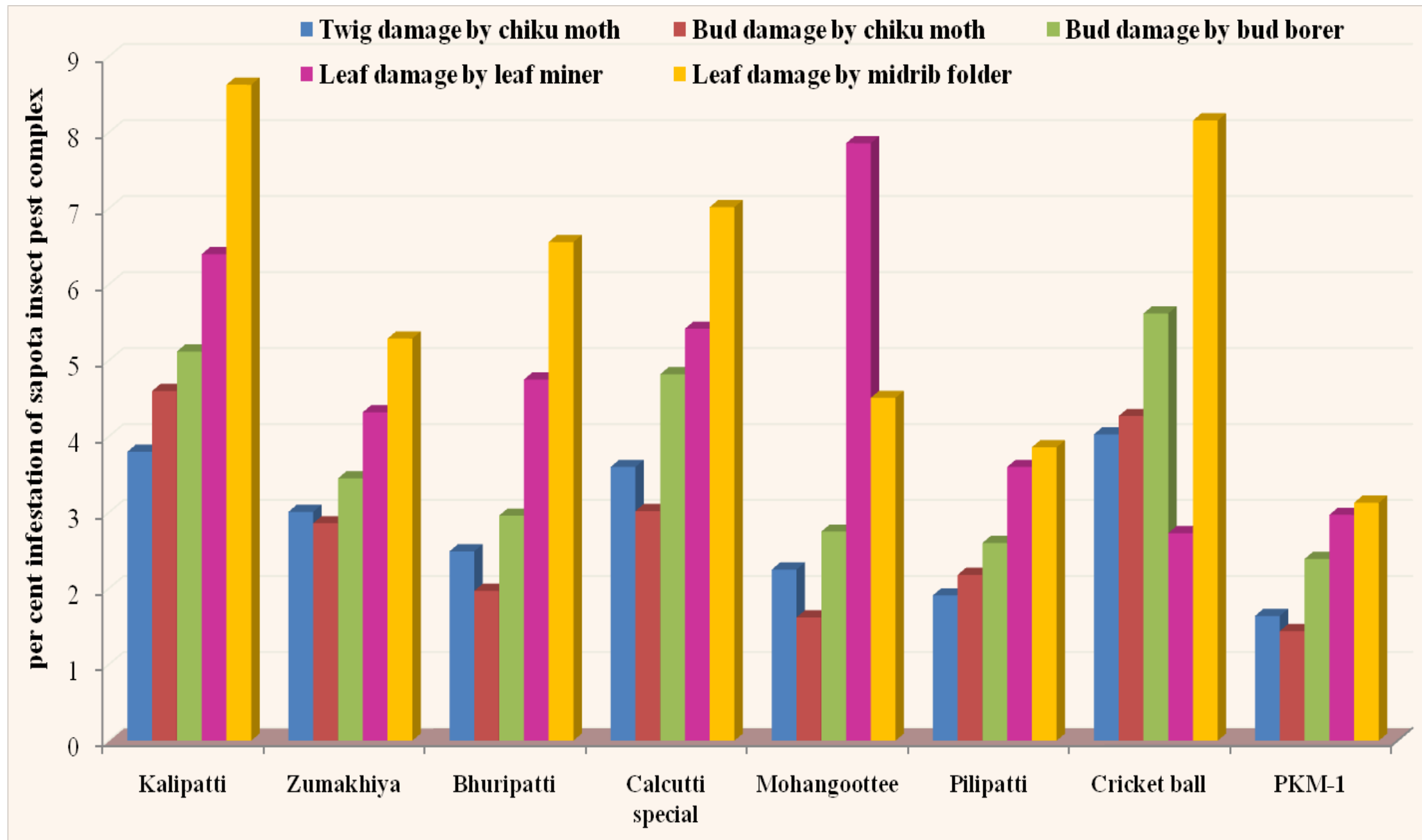

Figure 6: Varietal screening of sapota against infestation of sapota insect pest complex 
Varietal screening of sapota against infestation of bud borer

The result shown in Table 1 and graphically depicted in Figure 1 indicated that all varieties showed more or less bud damage. Among eight variety of sapota tested the variety of Cricket ball showed most susceptible 5.62 per cent infestation. While variety Mohangoottee showed moderately susceptible 2.75 per cent infestation followed by Bhuripatti, Zumakhiya, Calcutti special and Kalipatti were recorded 2.96, 3.45, 4.82 and 5.12 per cent infestation, respectively. Variety PKM-1 showed the least susceptible 2.39 per cent infestation and it was at par with Pilipatti 2.60 per cent infestation.

Varietal screening of sapota against infestation of leaf miner

The result shown in Table 1 and graphically depicted in Figure 1 indicated that all varieties showed more or less leaf damage. Among eight varieties of sapota tested the variety of Mohangoottee showed most susceptible 7.86 per cent infestation. While variety Pilipatti showed moderately susceptible 3.60 per cent infestation followed by Zumakhiya, Bhuripatti, Calcutti special and Kalipatti were recorded 4.32, 4.75, 5.42 and 6.40 per cent infestation, respectively. Variety Cricket ball showed least susceptible 2.73 per cent infestation and it was at par with PKM-1 2.97 per cent infestation.

Varietal screening of sapota against infestation of midrib folder

The result shown in Table 1 and graphically depicted in Figure 1 indicated that all varieties showed more or less leaf damage. Among eight varieties of sapota tested the variety of Kalipatti showed most susceptible 8.63 per cent infestation. While variety Pilipatti showed moderately susceptible 3.86 per cent infestation followed by Mohangoottee, Zumakhiya, Bhuripatti, Calcutti special and Cricket ball were recorded 4.51, 5.29, 6.56, 7.02 and 8.16 per cent infestation, respectively. Variety PKM-1 showed least susceptible 3.13 per cent infestation.

The results of present investigation are in conformation with Khambhu (2015) tested eight varieties of sapota, in which Kalipatti, DHS-2 and PKM-3 recorded highest bud damage. However, the rest of the varieties viz., PKM-1, PKM-4, DHS-1 and Cricket ball were found moderately susceptible to this pest. The study on varietal screening of sapota against bud borer was carried out during 2014-15 at gandevi, data indicated minimum bud damage was reported in Pilipatti (2.03\%), followed by PKM-5 (2.96\%) and Mohangoottee (2.97\%). However, the maximum bud damage $(5.33 \%)$ was reported in DHS-1, followed by Kalipatti $(5.27 \%)$ and DHS-2 (4.78\%) (Anon., 2015). Bisane and Naik (2016) tested the sixteen variety of sapota in which the lower bud damage of chiku moth, $N$. eugraphella was noticed in Bhuripatti, Singapore and Mohangoottee, as where the higher infestation on Pilipatti, DHS-1, Murabba and Paria Collection. Chirag and Bisane (2016) studied the eight varieties of sapota, they concluded that the leaf miner, A. gemoniella damage lower on Cricket ball while higher damage recorded on Kalipatti. However, PKM-1, PKM-3, DHS-1 and DHS2 were found moderately susceptible leaf miner, while PKM-1 was found moderately susceptible to midrib folder. Thus, present finding are more or less corroborating with previous findings. Among eight varieties of sapota tested against infestation, all varieties shown more or less infested by sapota insect pests. Among eight varieties, Cricket ball showed highly susceptible (4.03\% infestation) followed by Kalipatti (3.80\% infestation). While variety of PKM-1 shown least susceptible (1.64\% infestation) against twig 
damage of chiku moth. The variety Kalipatti shown most susceptible (4.60\% infestation), while PKM-1 shown the least susceptible (1.44\% infestation) against bud damage of chiku moth. The variety of Cricket ball shown most susceptible (5.62\% infestation), while Variety PKM-1 shown least susceptible (2.39\% infestation) followed by Pilipatti (2.60\% infestation) against bud damage of bud borer. The variety Mohangoottee shown most susceptible ( $7.86 \%$ infestation), while variety Cricket ball showed least susceptible (2.73\% infestation) followed by PKM-1 (2.97\% infestation) against leaves damage of leaf miner. The variety Kalipatti shown most susceptible (8.63\% infestation), while variety PKM-1 showed least susceptible $(3.13 \%$ infestation) against leaves damage of midrib folder.

\section{References}

Anonymous. (2015). Annual Research Report 2014-15. $11^{\text {th }}$ plant protection subcommittee (PPSC), Fruit Research Station, NAU, Gandevi. pp. 14-27.

Anonymous. (2018 a). Final estimate of area and production of horticulture crops 2016-2017. National Horticultural Board, Gurgaon, India. http://nhb.gov. in/statistics/State_Level/201617(Final).pdf

Anonymous. (2018 b). District wise estimated data in area and production of fruits crops in Gujarat state during 2016-17. https://doh.gujarat.gov.in/horticulturecensus-guj.htm

Bisane, K. D. and Naik, B. M. (2016). Varietal performance of sapota against bud and seed boring insect pests under South Guajrat condition. International Journal of Tropical Agriculture, 34(5): 1207-1210.

Butani, D. K. (1979). Insects and fruits. Periodical Expert Book Agency, Delhi pp. 87-94.

Cheema, G. S., Bhat, S. S. and Naik, K. C. (1954). Commercial fruit of India. McMillan and Co. Limited, Culcutta. pp. 422.

Chirag, V. K. and Bisane, K. D. (2016). Seasonal abundance of midrib folder and leaf miner on different varieties of sapota. International Journal of Tropical Agriculture, 34(4): 935-941.

Gandhi, S. R. (1956). Chiku in India, I.C.A.R., Farm Bullentin, New Delhi.

Khambhu, C.V. (2015). Seasonal abundance of important pest of sapota and evaluation of insecticides against seed borer M. Sc. (Agri.) Thesis, submitted to NAU, Navsari, India.

Reddy, M. G. (1959). Physico chemical investigations on sapota and its products. M.Sc. (Food Tech) Thesis submitted to, C.F.T.R.I., Mysore, Karnataka, India.

Singh, S., Krishnamurthy, S. and Katyal, S. I. (1963). Fruit culture in India. ICAR, New Delhi, pp. 192-198.

Tsomu, T., Patel, H. C., Thakkar, R. M., Ajang, M. and Vasara, R. P. (2015). Response of post-harvest treatments of chemical and plant growth regulators on biochemical characteristics of sapota fruit cv. kalipatti. The Bioscan, 10(1): $33-36$

\section{How to cite this article:}

Vaja, A.S., V.R. Virani, K.A. Chudasama and Dhandge, S.R. 2018. Varietal Screening of Sapota against Insect Pest Complex. Int.J.Curr.Microbiol.App.Sci. 7(11): 440-445. doi: https://doi.org/10.20546/ijcmas.2018.711.051 